\title{
Assessment of the environmental factor impact on health and economy of the coal region population
}

\author{
Valery Nesterov ${ }^{1}$, Olga Zonova ${ }^{2}$, Natalia Kudrevatykh ${ }^{2}$, Oksana Sheveleva ${ }^{2 *}$, and \\ Ekaterina Slesarenko ${ }^{2}$ \\ ${ }^{1}$ T.F. Gorbachev Kuzbass State Technical University, 650000 Kemerovo, 28 Vesennyaya st., Russian \\ Federation \\ ${ }^{2}$ T.F. Gorbachev Kuzbass State Technical University, Department of Finance and Credit, 650000 \\ Kemerovo, 28 Vesennyaya st., Russian Federation
}

\begin{abstract}
The anthropogenic impact of human activity has a significant influence not only on the incidence rate of the coal region, but also causes economic losses in the gross regional product. An important aspect of environmental diseases is the financial and economic losses that fall both on the state and the region, and directly on the citizens themselves. In the article, the assessment of the environmental factor impact on the coal region population health and economy is carried out by calculating the costs of treating diseases caused by unfavorable environmental conditions and determining the GRP losses associated with diseases and low life expectancy. At the same time, improving the quality of life of the population presupposes the conservation of a healthy human habitat, the preservation of human as a resource for the development of the region. In this regard, it is proposed to reduce the environmental load by implementing a concept aimed at improving regional environmental security by increasing investments in fixed assets related to environmental protection and rational use of natural resources; diversification of production by the transition mainly to manufacturing industries; increasing the environmental liability of managers of business entities, including through the action of compensatory mechanisms.
\end{abstract}

\section{Introduction}

The transition from the industrial stage of society development to the postindustrial one poses a dilemma for humanity: economic development or environmental stability with a permanent increase in the quality of life of people.

A significant part of the population currently lives in conditions of increased health risk due to the negative anthropogenic impact on the environment [1]. The situation is often aggravated by the low remuneration rate and social security, which limits the possibilities of citizens to receive high-quality timely medical care. As a result of the environmental

\footnotetext{
* Corresponding author: shob.fk@,kuzstu.ru
} 
factor impact, negative consequences arise both of social (a decrease in the compensation abilities of the body, a deterioration in the health of the population, a decrease in the birth rate with a simultaneous increase in the mortality rate) and economic nature (an increase in treatment costs, foregone earnings as a result of morbidity, shortfall in taxes and fees, GRP losses, etc.) [2].

Modern environmental and economic policies often not only contribute to the rapid depletion of resources and environmental pollution, but also hinder the harmonious development of the individual. The negative environmental situation, in turn, is determined by the nature and scale of the impact of industrial infrastructure [3].

Researchers began to talk about environmental problems affecting the quality of life of people back in the 1970s-1980s, when they realized the presence of negative consequences of economic growth without taking into account environmental factors, which is expressed in the deterioration of the environment and health of citizens.

A number of researchers agree that achieving a balance between economic growth and the state of environment is possible only with the implementation of the concept of sustainable development of territories, since a healthy and fruitful life of people is the result of harmonious human development with a careful attitude to natural resources [4]. However, despite the approval of this concept by the UN General Assembly, its provisions have not yet found practical application.

Other researchers propose the concept of "alternative civilization", which provides not quantitative, but qualitative growth, and assumes the formation of reasonable needs that will reduce the industrial load on the environment and ensure a high standard of living for citizens. The authors share this point of view, since further economic growth without taking into account environmental consequences is fraught not only with the depletion of the resource base, but also with the possible death of humanity [5-6].

One of the industries that have a fairly significant adverse impact on the environment is the coal industry. Thus, mining of 1 million tons of coal is on average accompanied by the disturbance of 1 ha of land. In the Kemerovo region, which is a typical coal-mining region, the situation is aggravated by the fact that about $60 \%$ of coal is mined by opencast mining, which entails the withdrawing of agricultural land, and dust and gas formation during drilling and blasting operations contributes to air pollution. Negative environmental consequences are observed both directly - in the form of a gassed atmosphere and a low quality of drinking water, and latently - affecting the genetic health of subsequent generations [7].

The determination of environmental factor impact on the population health as one of the indicators of assessing the negative impact on the economy of a region was carried out in the work according to the method of B.N. Porfiryev and S.N. Bobylev [8]. The method provides for the calculation of the costs of treating diseases caused by unfavorable environmental conditions, and the determination of GRP losses associated with incidence rate and low life expectancy of the population. The average share of the contribution of the environmental factor to the population health, according to experts, is about $20 \%$, of which about $9.5 \%$ is the level of influence of the air quality.

The rates of natural and migration increase/decline of the population are taken as indicators of the comfort of living in the region. The dynamics of these indicators for 2014-2018 indicate an increase in the natural decline in the Kemerovo region population. During this period, even simple reproduction of the population was not ensured in the region. High migration rates did not compensate for the decline in the population; a significant migration outflow there observed. This is largely due to the often noncompetitive wages, unfavorable environmental conditions and low life expectancy. In turn, the environmental situation made a negative impact on the economic and social development of the region. 
Air pollution has a significant effect on the incidence rate due to the effect of the sensitizing and cytotoxic effect of chemicals when they enter the body. The share of air samples exceeding the MPC in urban settlements of the Kemerovo region, reflects the upward dynamics of the analyzed indicators (Table 1). Saturation of air with highly toxic and carcinogenic substances exacerbates the negative environmental situation.

Table 1. The share of air samples exceeding the MPC for certain types of pollutants, $\%$

\begin{tabular}{|l|c|c|c|c|c|}
\hline Indicators & 2014 & 2015 & 2016 & 2017 & 2018 \\
\hline Benzapiren & 0 & 2.0 & 31.3 & 19.4 & 31.3 \\
\hline Hydrogen fluoride & 40.7 & 20.2 & 34.65 & 2.0 & 14.08 \\
\hline Dihydrosulfide & 0.6 & 3.1 & 16.16 & 12.7 & 13.7 \\
\hline Formaldehyde & 0.9 & 0.8 & 3.95 & 0.9 & 0.09 \\
\hline Carbon oxide & 0.6 & 0.8 & 2.32 & 2.4 & 2.7 \\
\hline $\begin{array}{l}\text { Suspended } \\
\text { substances }\end{array}$ & 1.2 & 1.5 & 2.15 & 1.6 & 2.2 \\
\hline
\end{tabular}

Exposure to chemicals causes an increase in congenital anomalies. Diseases of the digestive system, respiration, circulatory system, as well as neoplasms contribute to low life expectancy of the population in the region (Table 2).

Table 2. The share of deceased persons broken down by the main classes of causes of death in the Kemerovo region in the total number of deaths, \%

\begin{tabular}{|l|c|c|c|c|c|}
\hline Indicators & 2014 & 2015 & 2016 & 2017 & 2018 \\
\hline Neoplasms & 15.0 & 16.7 & 17.1 & 16.9 & 14.3 \\
\hline Diseases of & & & & & \\
\hline - circulatory system & 42.2 & 41.3 & 39.4 & 40.1 & 40.3 \\
\hline - respiration & 4.6 & 4.4 & 4.0 & 3.9 & 4.4 \\
\hline - digestive system & 5.0 & 5.3 & 5.2 & 5.2 & 5.7 \\
\hline
\end{tabular}

An important aspect of environmental diseases is financial and economic losses, which fall not only on the state and the region (through the provision of social protection, GRP losses, etc.), but also directly on the citizens themselves.

The assessment of the environmental factor impact on the health of citizens and the economy of the region are presented in Table 3 on the example of the Kemerovo region, as a territory for which environmental problems, including the problems of air pollution, are extremely relevant due to industrial orientation in general, and the structure of industry in particular (prevalence of coal, metallurgical, chemical industries, which are recognized as the largest air pollutants) (Table 3).

The budget expenditures of the Kemerovo region on health care for the analyzed period decreased by $37 \%$, despite the increase in the incidence rate and the increase in the average number of days of sickness absence per employee. 
On the contrary, GRP losses due to morbidity increased by $68 \%$. The increase in GRP losses as a result of morbidity by 16346 million rubles is due to a decrease in the number of employed and an increase in the number of days of sickness absence. Thus, the share of GRP losses due to morbidity in Kuzbass in 2014 was 3.2\%, and in 2018 it increased to $3.3 \%$.

Table 3. Assessment of the environmental factor impact on the Kemerovo region population health and the economy

\begin{tabular}{|c|c|c|c|c|c|}
\hline Indicators & 2014 & 2015 & 2016 & 2017 & 2018 \\
\hline \multicolumn{6}{|c|}{ Budget expenditures on health care } \\
\hline $\begin{array}{l}\text { Budget } \\
\text { expenditures on } \\
\text { health care, million } \\
\text { rubles }\end{array}$ & 18830.3 & 20537.6 & 20984.7 & 7833.4 & 11886.6 \\
\hline $\begin{array}{l}\text { Population, } \\
\text { thousand people }\end{array}$ & 2725 & 2717.6 & 2708.8 & 2694.9 & 2674.3 \\
\hline $\begin{array}{l}\text { Budget } \\
\text { expenditures on } \\
\text { health care per } \\
\text { capita, thousand } \\
\text { rubles }\end{array}$ & 6910.2 & 7557.3 & 7746.9 & 2906.7 & 4444.8 \\
\hline \multicolumn{6}{|c|}{ GRP losses due to morbidity } \\
\hline $\begin{array}{l}\text { The number of } \\
\text { people employed in } \\
\text { the economy, } \\
\text { thousand people }\end{array}$ & 1322.6 & 1270.7 & 1264.0 & 1244.2 & 1238.1 \\
\hline $\begin{array}{l}\text { Average number of } \\
\text { days of sickness } \\
\text { absence per } \\
\text { employee per year }\end{array}$ & 11.5 & 11.7 & 11.7 & 11.8 & 11.8 \\
\hline $\begin{array}{l}\text { GRP, million } \\
\text { rubles }\end{array}$ & 752024.0 & 843345.4 & 865325.3 & 1058430.4 & 1231598.6 \\
\hline $\begin{array}{l}\text { GRP per } 1 \\
\text { employed in the } \\
\text { economy per day, } \\
\text { rubles }\end{array}$ & 1579.43 & 1843.57 & 1901.65 & 2363.03 & 2763.19 \\
\hline $\begin{array}{l}\text { GRP losses as a } \\
\text { result of morbidity, } \\
\text { million rubles }\end{array}$ & 24023.0 & 27408.7 & 28123.1 & 34693.0 & 40369.0 \\
\hline \multicolumn{6}{|c|}{ GRP losses due to low life expectancy of the population } \\
\hline $\begin{array}{l}\text { Population, } \\
\text { thousand people }\end{array}$ & 2725 & 2717.6 & 2708.8 & 2694.9 & 2674.3 \\
\hline $\begin{array}{l}\text { Mortality rate, } \\
\text { people }\end{array}$ & 39763 & 39355 & 38872 & 38151 & 38748 \\
\hline $\begin{array}{l}\text { Mortality rate per } \\
1000 \text { people, } \\
\text { people }\end{array}$ & 14.6 & 14.5 & 14.4 & 14.2 & 14.5 \\
\hline $\begin{array}{l}\text { GRP per capita, } \\
\text { rubles }\end{array}$ & 275972.1 & 310327.3 & 319449.7 & 392753.1 & 460531,2 \\
\hline Life expectancy, & 67.80 & 68.31 & 68.72 & 69.35 & 69.32 \\
\hline
\end{tabular}




\begin{tabular}{|l|c|c|c|c|c|}
\hline years & & & & \\
\hline $\begin{array}{l}\text { The number of } \\
\text { years by which the } \\
\text { average life } \\
\text { expectancy is less } \\
\text { than the aggregate } \\
\text { physiological age } \\
\text { of 89 years, years }\end{array}$ & 21.2 & 20.7 & 20.3 & 19.7 & 19.7 \\
\hline $\begin{array}{l}\text { The number of } \\
\text { man years of } \\
\text { average life } \\
\text { expectancy that is } \\
\text { less than the } \\
\text { aggregate } \\
\text { physiological age } \\
\text { of 89 years, } \\
\text { thousand of man } \\
\text { years }\end{array}$ & 843.4 & 815.7 & 791.8 & 753.9 & 763.9 \\
\hline $\begin{array}{l}\text { GRP losses due to } \\
\text { low life expectancy } \\
\text { of the population, } \\
\text { million rubles }\end{array}$ & 22112.8 & 24047.4 & 24030.4 & 28128.1 & 33421.6 \\
\hline $\begin{array}{l}\text { Treatment costs, } \\
\text { million rubles }\end{array}$ & 4472.2 & 4877.7 & 4983.9 & 1860.4 & 2823.1 \\
\hline $\begin{array}{l}\text { Damage to public } \\
\text { health, billion } \\
\text { rubles }\end{array}$ & 2742.4 & 2995.2 & 3010.2 & 3162.0 & 3807.6 \\
\hline $\begin{array}{l}\text { Budget revenues, } \\
\text { million rubles }\end{array}$ & 95577.7 & 102591.0 & 105076.2 & 136138.3 & 168676.0 \\
\hline $\begin{array}{l}\text { Amount of lost } \\
\text { budget revenues, } \\
\text { million rubles }\end{array}$ & 3100.5 & 3242.1 & 3242.4 & 4041.8 & 5102.6 \\
\hline $\begin{array}{l}\text { Budget losses from } \\
\text { air pollution, } \\
\text { million rubles }\end{array}$ & 464.5 & 493.3 & 497.4 & 454.7 & \\
\hline
\end{tabular}

In turn, the GRP losses due to low life expectancy amounted to 33421.6 million rubles in 2018. At the same time, there is a clear negative trend - an increase in this indicator over five years by $51 \%$.

The amount of lost budget revenues also has a negative tendency: there is a permanent increase during the analyzed period. So, in general, the amount of lost income increased by more than 1.6 times over the period.

The long-term program for the development of the coal industry in Russia for the period up to 2030 involves a gradual increase in production, which may lead to further damage of both natural landscapes and human health.

At the same time, improving the quality of life of the population presupposes the conservation of a healthy human habitat, the preservation of human as a resource for the development of the region. Full-fledged, high-quality and sustainable development of the region is possible only with the reasonable exploitation of the natural resources.

In this regard, the National Project "Ecology" was developed and is being implemented in the Russian Federation, within the framework of which the Federal Project "Clean Air" is 
being implemented. The implementation of the project involves reducing the air pollution rate in industrial centers by creating a system for monitoring the air quality using the online emission control data, equipping Rospotrebnadzor (Federal Service for Surveillance on Consumer Rights Protection and Human Wellbeing) testing laboratories with modern equipment, improving the procedural framework.

Important areas in the field of improving the environmental situation in the region, which have a beneficial effect on the population health and the economic development level, can also be:

- increasing investment in fixed assets for environmental protection and rational use of natural resources [9];

- expansion of forests and meadows, which will allow the absorption of a significant part of harmful emissions into the air;

- development of a program for diversification of production by the transition mainly from raw material extraction industries to manufacturing industries that have a less harmful effect on the environment [10]. The oil and coal mining industries are among the main "suppliers" of harmful substances and greenhouse gases to the air [11];

- reduction in the share of worn-out and obsolete industrial equipment (including that of environmental nature), which often does not allow for efficient capture of harmful emissions and discharges;

- rational and economical use of fuel for energy and heat supply of industrial needs and households, transition to more environmentally friendly types of energy [12];

- increasing the environmental liability of the owners and managers of enterprises, for example, through the action of compensatory mechanisms. A. Bobkova, N. Andryeyeva, L. Verbivska, V. Kozlovtseva, V. Velychko and other proposes the introduction of medical and social insurance in areas with an unfavorable environmental situation, which is based on hedging using derivative financial instruments [13-16]. There are three parties involved in the transaction: residents of the contaminated area, the source of the area's pollution and the insurance fund. The essence of this type of insurance is to transfer the risk of deteriorating public health to another party - an insurance fund for a fee that is paid by the polluter. Thus, the polluter is directly (through the remuneration paid) responsible for the public health risk.

- creation of a developed system of environmental education in order to increase the environmental responsibility of the population.

\section{References}

1. P. Hryhoruk, N. Khrushch, S. Grygoruk, Svitlana. IOP Conf. Ser.: Earth and Env. Sci. 628, 012026 (2021)

2. E. Slesarenko, E. Radionova, O. Sheveleva, N. Kudrevatykh, T. Mamzina. IOP Conf. Ser.: Earth and Env. Sci. Ser. 224, 012043 (2019)

3. V. Vasiliev, V. Sushko, N. Dekhanova, N.G. Ecol. and Ind. of Rus. 23, 64 (2019)

4. S. Bereznev, O. Zonova, E. Kulpina. E3S Web of Conf. IIMS 2018: Electr. ed. (2018)

5. L. Beesley. Procedia Env. Sci. 21, 1 (2014)

6. Y. Chen IOP Conf. Series: Earth and Env. Sci. 199, 022067 (2018)

7. E. Ganebnykh, T. Burtseva, A. Petuhova, A. Mottaeva. E3S Web of Conf. 91, 08035 (2019)

8. B. N. Porfiryev, S.N. Bobylev Stud. on Rus. econ. devel. 29(2), 116 (2018)

9. I. Kropsz-Wydra. Roczniki Naukowe Stowarzyszenia Ekon. Rolnictwa i Agrobiz. 21, 244 (2019) 
10. E. Egidarev, V. Bocharnikov, I. Lindberg, I. IOP Conf. Ser.: Earth and Env. Sci. 629, 012068 (2021)

11. A. Khokhryakov, I. Larionova, O. Moskvina, E. Tseytlin. Min. inform. and analyt. bull. 501 (2020)

12. A. Kuchumov, R. Fattakhov, O. Pivovarova, S. Pobyvaev, A. Gibadullin, D. Troshin. IOP Conf. Ser.: Earth and Env. Sci. 548, 062022 (2020)

13. O. Zonova, E. Slesarenko, E. Nekhoda. The 8 th rus.-chin. symp. Coal in the 21 st cent. 125 (2016)

14. A. Bobkova, N. Andryeyeva, L. Verbivska, V. Kozlovtseva, V. Velychko. Stud. of Appl. Econ. 38 (2021)

15. A. Kasych, P. Suler, Z. Rowland. Sust. 12, 9589 (2020)

16. O. Litovchenko, K. Zub, I. Zavgorodnii, V. Myasoedov. Inter. Col. 5, 155 (2018) 